\title{
Sustainability Reporting By Universities In Indonesia
}

\section{Abstract}

\author{
BIROWO YASBIE \\ ZUNI BAROKAH \\ Universitas Gadjah Mada
}

\begin{abstract}
This study aims to describe sustainability reporting practices by universities in Indonesia by knowing the reporting channel used by universities and the conformity of information disclosure with GRI G4 indicator and campus sustainability assessment instrument. This study uses a framework with 73 indicators based on GRI and a campus sustainability assessment instrument to analyze information disclosed by universities in Indonesia. The results of the analysis show that the level of disclosure of sustainability information conducted by universities in Indonesia is lower when compared with universities in Canada and Lithuania. Disclosure of information undertaken by universities in Indonesia remains limited in scope, and no universities disclose sustainability information in an integrated report.
\end{abstract}

Keywords: Sustainability reporting, GRI, University, Legitimacy Theory

Intisari: Penelitian ini bertujuan untuk mendeskripsikan praktik pelaporan keberlanjutan oleh perguruan tinggi di Indonesia dengan mengetahui saluran pelaporan yang digunakan oleh universitas dan kesesuaian pengungkapan informasi dengan indikator GRI G4 dan instrumen penilaian keberlanjutan kampus. Penelitian ini menggunakan kerangka kerja dengan 73 indikator berdasarkan GRI dan instrumen penilaian keberlanjutan kampus untuk menganalisis informasi yang diungkapkan oleh universitas di Indonesia. Hasil analisis menunjukkan bahwa tingkat pengungkapan informasi keberlanjutan yang dilakukan oleh universitas di Indonesia lebih rendah bila dibandingkan dengan universitas di Kanada dan Lithuania. Keterbukaan informasi yang dilakukan oleh universitas di Indonesia masih terbatas dalam ruang lingkupnya, dan tidak ada universitas yang mengungkapkan informasi keberlanjutan dalam laporan terpadu.

Kata Kunci: Pelaporan Keberlanjutan, GRI, Universitas, Teori Legitimasi

*Corresponding author: zuni.b@ugm.ac.id 


\section{Introduction}

The increasing attention and awareness of the environment require economic growth and development to not only generate profits, but they must also focus on human and environmental aspects through the concept of triple bottom line (profit, people, planet). Brundtland (1987) defines sustainable development as a development that meets current needs without neglecting the ability of future generations to meet their needs. Sustainability development has become an unwritten norm for governments and several economic sectors, including universities (Fonseca et al. 2011). Sustainability report will enable the entity to communicate to their stakeholders its role and contribution to sustainable development. Although there have been many studies on sustainability reporting, there are still few that examine the sustainability reporting by universities. Even though universities have an essential role in sustainable development in this several areas:

a. Research on sustainability development;

b. Green campus operation activities and social initiatives to increase society life around university area;

c. Involvement in society life;

d. Sustainability development education; and

e. Assesment and reporting.

Therefore, this study aims to answer some questions related to the practice of sustainability reporting by universities in Indonesia and to describe the efforts of universities in communicating their role in sustainable development to their stakeholders.

\subsection{Research questions}

1. How is the practice of sustainable information disclosure by universities in Indonesia?

2. What sustainability information has been disclosed by universities in Indonesia? 
3. How is the conformity of sustainability information disclosed by universities in Indonesia with the GRI G4 indicator and campus sustainability assessment tools?

\subsection{Research objective}

1. Describe the sustainable reporting practice by universities in Indonesia,

2. Assess the conformity of sustainability reporting by universities with GRI G4 standards and campus sustainability assessment instruments.

\section{Literature Review}

\subsection{Stakeholder Theory}

Stakeholders are groups or individuals who are affected by the positive and negative impacts of organizational activities and are parties whose rights are valued or violated by organizational activities (Freeman 1984). Marshall et al. (2010) stated that university leaders must act as agents of all stakeholders and should communicate with all stakeholders through sustainability reporting. Participating in sustainable development is one of the ways universities can do to create better and more sustainable community conditions and indirectly will make universities continue (sustain).

All university effort in sustainable development must be accessible to all stakeholders, and this can be realized through sustainability reporting. In the context of sustainability reporting, universities can carry out sustainability reporting to meet the information needs of stakeholders and convince their stakeholders that universities have carried out operations that are in line with the interests of stakeholders.

\subsection{Legitimacy Theory}

Legitimacy is understood as a general perception or assumption that an entity's actions are desired, appropriate, or compatible with social constructs such as norms, values, beliefs, and definitions (Suchman 1995, 574). Lindblom (1994) defines legitimacy as a condition or status that exists when the organizational value system is following the value system of the social system in which the organization is located. When there is a potential difference in the value system, there is a threat to the legitimacy of the organization. 
Sustainability reports can help universities to obtain or maintain approval from the community and with that approval, the organization can sustain. Sustainability information disclosure can also be a tool for universities to demonstrate their responsibility and concern towards the environment and society. Sustainability reports can be used by universities to build trust and credibility with increased transparency. The community and the government can also assess the suitability of higher education operations with the norms and values that apply in the community through sustainability reports. By revealing sustainability information, universities convey messages to their stakeholders that their operations are in line with the expectations of the stakeholders and indirectly maintain their legitimacy.

\subsection{Sustainability Development}

The definition of sustainable development, according to the Brundtland Report (1987), is a development that meets current needs without neglecting the ability of future generations to meet their own needs. Universities can facilitate the need for thoughts about sustainability through teaching, curriculum, and research. Education is a core component in achieving a sustainable world (Zachariou, Kaila, and Katsikis 2008). Higher education is a "form of community value" and "an organization that influences sustainable development" (Godemann et al. 2014).

\subsection{Sustainability Reporting}

Sustainability reports are essential to evaluate and encourage the involvement of universities in sustainable development. Sustainability reporting can be used as a tool to evaluate and communicate the involvement of universities in sustainability development. Sustainability reporting is a voluntary activity with two main objectives: (1) to assess organizational progress towards sustainability, and (2) to communicate the organization's business progress in the environmental and social dimensions to stakeholders (Dalal-Clayton and Bass 2002; Global Reporting Initiative 2014).

Sustainability reporting by universities is needed to identify and fulfill the expectations of stakeholder groups and to build communication channels with 
stakeholders. Sustainability reporting allows universities to be transparent about the obligations of accountability and service (Alonso-Almeida et al. 2014). Sustainability reporting by universities aims to communicate the mission and values of tertiary institutions, operations and performance activities related to sustainability issues that cannot be met by traditional reporting by universities that only focus on research projects, publications, patents, graduates, curriculum and financial information (Garde, Rodríguez, and López 2013).

\section{Research Method}

\subsection{Research Design}

This research is descriptive. Research, whose purpose is to describe a problem, situation, and event. Descriptive research is usually designed to collect data that allows researchers to describe a person, event or situation. This type of research can help researchers to understand the characteristics of a group in certain situations (Sekaran and Bougie 2013, 97).

\subsection{Population and Sample}

The population of this study is universities in Indonesia. The number of universities in Indonesia registered in the Ministry of Technology, and Higher Education Research of the Republic of Indonesia in 2017 is 3,276. The sample used in this study is 20 universities which are the 20 best universities in the Dikti ranking in 2017. Because the sample is selected from the best universities, it will reflect the best practices and trends of universities in Indonesia.

\subsection{Research Instrument}

The research instruments used in this study are indicators adopted from the GRI G4 reporting guidelines and campus sustainability assessment tools. The researcher used the GRI G4 guide in this study for two reasons. First, compared to other sustainable reporting guidelines, GRI has a better background of experimentation. To date, the GRI guide has become a reference guide to sustainable reporting throughout the world. The 
reason for the two authors using the GRI G4 guide is that GRI is considered as a tool that can harmonize many approaches related to sustainable reporting by universities (Lozano 2006b; Newport, Chesnes, and Lindner 2003). The limitations of the GRI guidelines do not include indicators related to sustainability in research, environmentally friendly buildings, canteens, and other issues relevant to universities (Fonseca et al. 2011). To fill these limitations, the researchers used a framework of 20 indicators of campus sustainability assessment instruments adopted from the research of Fonseca et al. (2011).

\subsection{Data Collection Technique}

The data collection technique used in this study is document observation. The type of data used in this study is secondary data, namely the data that is publicly available which is contained in universities reports and websites.

\subsection{Data Analysis Technique}

The analytical method used in this study is content analysis. Content analysis is a research technique used to produce conclusions that can be replicated and are valid from the text (or other things) in the context of its use (Krippendorff 2004, 18). DowneWamboldt (1992) describes content analysis as a research method that provides a systematic and objective way to make valid conclusions from verbal, visual or written data with the aim of describing and quantifying specific phenomena. The qualitative content analysis includes four stages, namely planning, data collection, data analysis and compilation which are elaborated as follows (Bengtsson 2016):

1. Planning

All research will begin by determining what researchers want to find out, from whom and how (Bengtsson 2016). At this stage, the determination of objectives, samples, and unit of analysis is carried out.

2. Data Collection

Research questions in this study will be answered using analysis of data in the form of information and reports published in 2017 and university websites. 


\section{Data Analysis}

The data analysis phase aims to organize and obtain meaning from the data collected so that conclusions can be made that are valid and realistic (Polit and Beck 2006). The data analysis process includes four steps, namely decontextualization, recontextualization, categorization, and compilation. All stages in the content analysis in this study will be included in the appendix section. The following are the four stages of the data analysis process:

a. Decontextualisation

In this process, the researcher read the data and make a list of codes. The researcher must make a list and explanations of codes to reduce cognitive changes in the analysis process to maintain reliability (Downe-Wamboldt 1992; Morse and Richards 2002). In this study, a list of tick box frame codes was adopted from GRI G4 reporting standards and campus sustainability assessment tools adopted from the research of Fonseca et al. (2011).

b. Recontextualisation

In this process, researchers identify and label meaningful units in the data with codes based on existing indicators, then researchers re-read the original text and ensure all meaningful units have been recorded (Bengtsson 2016).

c. Categorization

In this process, researcher group report and information data published by universities into categories that are made based on GRI G4 reporting standards and campus sustainability assessment tools adopted from the research of Fonseca et al. (2011).

d. Compilation

In the compilation process, researchers carry out the analysis process by category, conduct reliability testing and make conclusions. Internal reliability was obtained when independent researchers re-analyzed the information and found the same results as the original researchers (Zohrabi 2013). According to Milne and Adler (1999), reliability in content analysis can be tested using two methods: 
1. Proof that the data produced from the analysis process is reliable.

2. Reliability is related to coding instruments.

Because the coding instrument used in this study was taken from the GRI reporting guide, which is the most widely used sustainability reporting guide in the world and the campus sustainability assessment instrument adopted from the research of Fonseca et al. (2011) which has gone through previous

reliability testing, then the reliability testing that will be conducted in this study is only to test the reliability of the data produced.

The most common way to prove the reliability of the data produced is to use multiple coder methods and compare the differences between the coder or analyze the differences that exist and then solve it with a discussion between coder (Milne and Adler 1999). In this study, researchers asked colleagues who had accounting knowledge to retest the disclosure assessments that had been carried out by universities using the GRI G4 standard and campus sustainability assessment instruments.

4. Report and Presentation

The report of a research effort is an official review of what was done, why the research was carried out, the results and the contribution to existing knowledge (Krippendorff 1991, 291-292). The reporting and presentation phase allows the rationality of research results to be evaluated by various parties.

\section{Result And Discussion}

\subsection{Description of the Research Object}

The object of this research is universities in Indonesia. The sample used in this study is 20 universities which are the 20 best universities according to the Ministry of Technology and Higher Education Research of the Republic of Indonesia in 2017. The 20 best universities are Universitas Gadjah Mada (UGM), Institut Teknologi Bandung (ITB), Institut Pertanian Bogor (IPB), Universitas Indonesia (UI), Institut Teknologi Sepuluh Nopember (ITS), Universitas Diponegoro (UD), Universitas Airlangga (UA), Universitas Brawijaya (UB), Universitas Hasanuddin (UH), Universitas Negeri 
Yogyakarta (UNY), Universitas Sebelas Maret (UNS), Universitas Andalas (UAN), Universitas Pendidikan Indonesia (UPI), Universitas Padjajaran (UP), Universitas Negeri Malang (UNM), Universitas Negeri Semarang (UNES), Universitas Udayana (UU), Universitas Lampung (UL), Universitas Sumatera Utara (USU), and Universitas Jember (UJ). Sources of research data were obtained through financial reports, annual reports, rector's reports, and websites of each university. Information about the complete data source is presented in Table 4.1.

How is the practice of sustainable information disclosure by universities in Indonesia?

The results of an analysis of sustainability information disclosure by universities show that the most widely used channel of sustainability information disclosure by universities are websites (20), financial reports (15), annual reports (8), and the least widely used is the rector's report (3). These results indicate that the practice of sustainability information disclosure by universities in Indonesia still takes various forms. Table 4.1 shows the information channels used by each university.

In the identification process in this study, sustainability information channel is categorized as coming from financial reports, annual reports, rector reports and websites with the following conditions:

1. Financial statements, if university publishes the income statement and balance sheet.

2. Annual report, if the university publishes a report that has a one-year period. Some universities that are the sample of this study have different annual report titles.

3. Rector's report, if the college publishes the rector's speech in the form of a rector's report.

4. The website, if the university has a website that contains information about the organization's profile and study program information. For the website address of each university, is included in the appendix section. 
The Indonesian Journal of Accounting Research - Sep, Vol. 21 , No.3, 2018

Table 4. 1

Sustainability Information Channel used by Universities

\begin{tabular}{|c|c|c|c|c|c|c|}
\hline \multirow[b]{2}{*}{ No. } & \multirow[b]{2}{*}{$\begin{array}{l}\text { University } \\
\text { Name }\end{array}$} & \multicolumn{4}{|c|}{ Sustainability Information Channel } & \multirow{2}{*}{$\begin{array}{l}\text { Percenta } \\
\text { ge of } \\
\text { Availabi } \\
\text { lity of } \\
\text { Informa } \\
\text { tion } \\
\text { Channel } \\
\end{array}$} \\
\hline & & $\begin{array}{l}\text { Financial } \\
\text { Report }\end{array}$ & $\begin{array}{c}\text { Annu } \\
\text { al } \\
\text { Repo } \\
\text { rt }\end{array}$ & $\begin{array}{l}\text { Rector's } \\
\text { Report }\end{array}$ & $\begin{array}{l}\text { Websit } \\
\text { e }\end{array}$ & \\
\hline 1 & $\begin{array}{l}\text { Universitas Gadjah } \\
\text { Mada }\end{array}$ & $\checkmark$ & & $\checkmark$ & $\checkmark$ & $75 \%$ \\
\hline 2 & $\begin{array}{l}\text { Institut Teknologi } \\
\text { Bandung }\end{array}$ & $\checkmark$ & & & $\checkmark$ & $50 \%$ \\
\hline 3 & Institut Pertanian Bogor & $\checkmark$ & $\checkmark$ & & $\checkmark$ & $75 \%$ \\
\hline 4 & Universitas Indonesia & $\checkmark$ & $\checkmark$ & & $\checkmark$ & $75 \%$ \\
\hline 5 & $\begin{array}{l}\text { Institut Teknologi } \\
\text { Sepuluh Nopember }\end{array}$ & & & & $\checkmark$ & $25 \%$ \\
\hline 6 & Universitas Diponegoro & & & & $\checkmark$ & $25 \%$ \\
\hline 7 & Universitas Airlangga & $\checkmark$ & & & $\checkmark$ & $50 \%$ \\
\hline 8 & Universitas Brawijaya & $\checkmark$ & $\checkmark$ & & $\checkmark$ & $75 \%$ \\
\hline 9 & Universitas Hasanuddin & $\checkmark$ & $\checkmark$ & & $\checkmark$ & $75 \%$ \\
\hline 10 & $\begin{array}{l}\text { Universitas Negeri } \\
\text { Yogyakarta }\end{array}$ & $\checkmark$ & $\checkmark$ & & $\checkmark$ & $75 \%$ \\
\hline 11 & $\begin{array}{l}\text { Universitas Sebelas } \\
\text { Maret }\end{array}$ & $\checkmark$ & & $\checkmark$ & $\checkmark$ & $75 \%$ \\
\hline 12 & Universitas Andalas & $\checkmark$ & & & $\checkmark$ & $50 \%$ \\
\hline 13 & $\begin{array}{l}\text { Universitas Pendidikan } \\
\text { Indonesia }\end{array}$ & $\checkmark$ & & & $\checkmark$ & $50 \%$ \\
\hline 14 & Universitas Padjajaran & $\checkmark$ & $\checkmark$ & & $\checkmark$ & $75 \%$ \\
\hline 15 & $\begin{array}{l}\text { Universitas Negeri } \\
\text { Malang }\end{array}$ & $\checkmark$ & & & $\checkmark$ & $50 \%$ \\
\hline 16 & $\begin{array}{l}\text { Universitas Negeri } \\
\text { Semarang }\end{array}$ & $\checkmark$ & $\checkmark$ & $\checkmark$ & $\checkmark$ & $100 \%$ \\
\hline 17 & Universitas Udayana & & & & $\checkmark$ & $25 \%$ \\
\hline 18 & Universitas Lampung & & & & $\checkmark$ & $25 \%$ \\
\hline 19 & $\begin{array}{l}\text { Universitas Sumatera } \\
\text { Utara }\end{array}$ & $\checkmark$ & $\checkmark$ & & $\checkmark$ & $75 \%$ \\
\hline 20 & Universitas Jember & & & & $\checkmark$ & $25 \%$ \\
\hline & Total & $15(75 \%)$ & $\begin{array}{c}8 \\
(40 \% \\
) \\
\end{array}$ & $3(15 \%)$ & $\begin{array}{c}20 \\
(100 \%)\end{array}$ & \\
\hline
\end{tabular}


Based on the identification results from table 4. 1, the most popular channel of information disclosure used by universities is the website. The majority of information disclosed on university websites is information on the standard categories of general disclosures, namely organizational profiles, study programs, research, college projects, governance, and ethics and integrity.

Some universities like Universitas Indonesia, Universitas Negeri Yogyakarta, Universitas Padjajaran, and Universitas Sumatera Utara enclose their financial statements in the annual report while Universitas Sebelas Maret encloses its financial statement on rector's report. Five universities namely Institut Teknologi Sepuluh Nopember, Universitas Diponegoro, Universitas Udayana, Universitas Lampung and Universitas Jember does not include the financial statements in the annual report, the rector's report, and the website. The non-publication of financial reports by several universities shows that some universities are less concerned about the information needs of stakeholders, this is reflected in the lack of access to information for stakeholders. For information disclosed by universities in the available channel of information, disclosure will be discussed more detail in the next sub-chapter.

\section{What has sustainability information been disclosed by universities in Indonesia?}

The three categories and subcategories most commonly disclosed by universities in Indonesia are general standard disclosures (69\%), research (65\%) and economics (48\%). This is because the indicators in the general standard disclosures and economic disclosures such as profiles, strategies, and economic performance are common things disclosed by an entity, while research is one of the main activities of universities. Therefore, it is only natural that universities widely disclose this subcategory. The least disclosure subcategories are human rights (8\%), communities (17\%), and green buildings and procurement (19\%). This percentage shows that the disclosures made by Indonesian universities are still limited in scope. The following graph 4.1 shows the level of disclosure of sustainability information by universities. 
Graph 4.1

Level of Disclosure of Sustainability Information by Universities

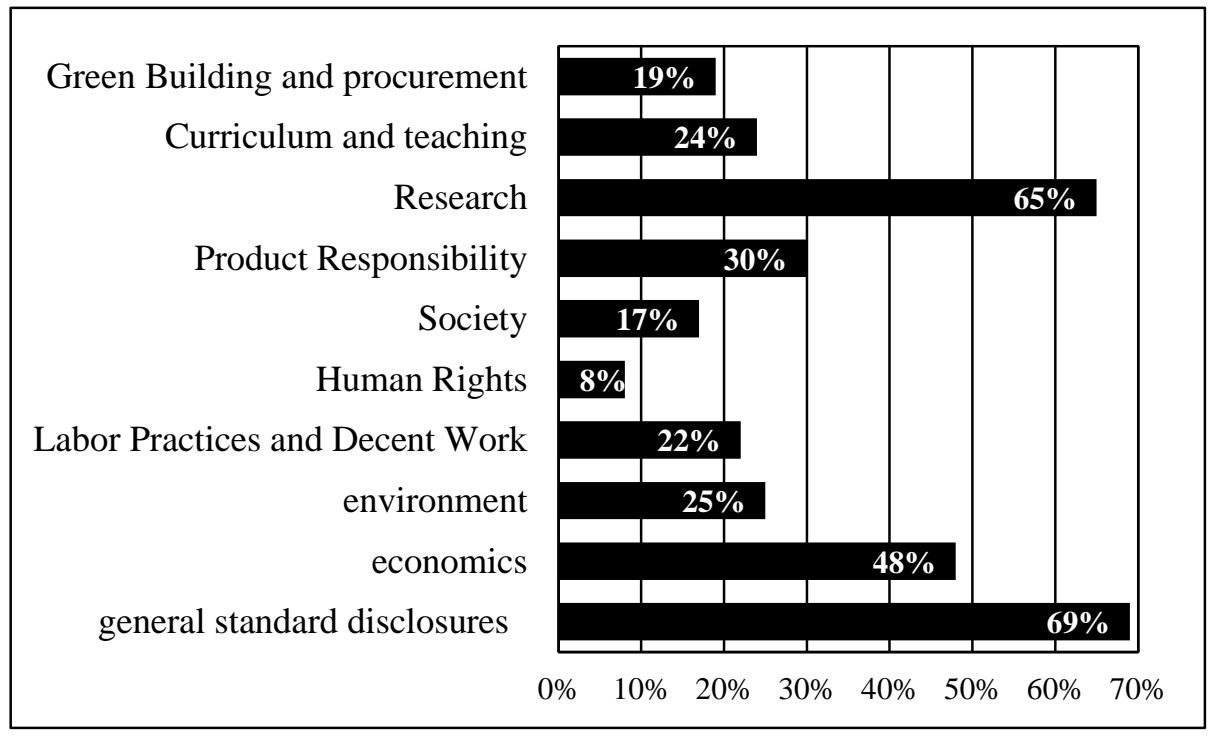

The low disclosure of several indicators by universities can be caused by the following:

1. Universities don't do practice related to information in indicators,

2. Universities have carried out practices related to information in indicators, but because of the insufficient and unintegrated documentation process, universities are not able to disclose this information,

3. Indonesian universities only disclose information to authorities, so the information cannot be accessed by the public.

The results of the analysis show that the use of the GRI guidelines to assess the sustainability of universities still requires a lot of adjustments because many indicators in GRI that are related to human rights, society, and labor practices are still not reported by universities. Although universities can create new policies or programs to report these indicators, the cost-benefit constraints of the implementation of the new policies must be considered. There are more important indicators to be equipped by universities such as environmentally friendly buildings and curriculum. This opinion is supported by the argument from Fonseca et al. (2011) and Orr and Eagan (1992) below. 
Buildings have a pedagogic role in the lives of students, staff, and faculty (Fonseca et al. 2011). The design of the building and the landscape of the college does not seem to influence the education process, but the fact is that buildings and landscapes reflect hidden curricula that have a strong influence on the educational process (Orr and Eagan 1992).

In the context of higher education, research and education are the main activities of the organization. The number of significant disclosures in the research indicator shows that Indonesian universities have attempted to measure the progress of their research activities. While the low disclosure of curriculum and teaching indicators shows that universities in Indonesia have not systematically measured the progress in implementing the principle of sustainability in lecture material. The low disclosure of curriculum and teaching indicators represents the absence of cultivating the principles of sustainability through teaching activities held by Indonesian universities. This shows that universities in Indonesia still have not contributed to sustainable development through the cultivation of ideas.

How is the conformity of sustainability information disclosed by universities in Indonesia with the GRI G4 indicator and campus sustainability assessment tools?

Based on the results of the data codification, it appears that the average Indonesian universities only disclose $31 \%$ of the indicators. The university with the most comprehensive disclosure was Universitas Negeri Semarang (45 indicators, 62\% appropriate), and the one which least comprehensive disclosed indicators was Universitas Udayana (10 indicators, $14 \%$ appropriate). With the average rate of disclosures at $31 \%$ with only $10 \%$ ( 2 universities) have a percentage of conformity above $50 \%$, it can be concluded that the disclosure of sustainability information by universities in Indonesia is still relatively low when compared to universities in Canada, which have a $37 \%$ rate of disclosure and universities in Lithuania which have a $48 \%$ rate of disclosure. 
From the 20 samples, there are also no universities that disclose sustainability information in one integrated report. This is due to the absence of rules that require universities to issue integrated sustainability reports. The following possibilities can cause the low disclosure and lack of integration of sustainability information disclosed by Indonesian universities:

1. Sustainable development has not become a goal and has not been considered important by Indonesian university stakeholders. This led to the low demands of the stakeholders to universities to disclose sustainability information. The low demands of the stakeholders caused low disclosure by universities.

2. The lack of concern for the environment has resulted in environmentally friendly operations not being the norm in Indonesian society so that the level of sustainable information disclosure does not affect the legitimacy of universities.

3. Stakeholders of universities did not expect sustainability practices by universities so that the disclosures made by universities have fulfilled the expectations of stakeholders. Or the expectations of the stakeholders have not been met, but because of the lack of complaints channels of dissatisfaction, the stakeholders' dissatisfaction is not conveyed.

Apart from the above possibilities, universities still have a moral obligation to educate the public about the impact of their operations on the environment. Indonesian universities also need to improve the disclosure of sustainability information that they have done.

\section{Conclusion}

Related to the first research question, the reporting channels and report forms used by universities in Indonesia are still diverse, and the most popular reporting channels used by universities are websites. There are still universities that do not present financial reports. Reports generated by universities are still not integrated. 
Related to the second research question, some conclusions can be drawn as follows: a). The categories and subcategories most disclosed by universities are general standard disclosures with an average of $69 \%$. Research with an average of $65 \%$, and the economy with an average of $48 \%$. The subcategories that were least disclosed were human rights with an average of $8 \%$, community with an average of $17 \%$, and green buildings and procurement with an average of $19 \%$. This result showed that the information disclosed by universities is still limited to the scope of the organization's profile, strategy, and governance. The disclosure of specific disclosure standards, especially those related to the environment and society is still low. B). The low disclosure of several indicators by universities can be caused by the following: (1) universities do not practice-related information in indicators, (2) universities have carried out practices related to information in indicators, but because of insufficient and unintegrated documentation process, universities are not able to disclose this information, (3) Indonesian universities only disclose information to authorities, so the public can not access the information. C). Numerous adjustment is necessary for the use of GRI guidelines to assess the sustainability of universities because many indicators in GRI that are related to human rights, community, and labor practices are yet to be reported by universities. Although universities can create new policies or programs to report these indicators, the costbenefit constraints of the implementation of the new policies must be considered. D). It is essential for Indonesian universities to complete the disclosure of information related to environmentally friendly buildings and curriculum. Two arguments support this conclusion, namely the argument from Fonseca et al. (2011) and Orr and Eagan (1992) described in chapter 4.

Related to the third research question, some conclusions can be drawn as follows: a). With average conformity of $31 \%$, sustainability information disclosure by universities in Indonesia is still relatively low compared to universities in Canada whose average conformity is $37 \%$ and universities in Lithuania whose conformity is $48 \%$. B). The low disclosure of sustainability information by Indonesian universities shows that the demands of the world community in several international declarations have not been 
effective in influencing Indonesian universities to make changes in the practice of education and policy-making that are more environmentally friendly. C). Of the 20 research sample, Universitas Negeri Semarang obtained the highest percentage of disclosure of $62 \%$ with the suitability of information disclosure with the GRI G4 standard and the Campus Sustainability Assessment Instrument as many as 45 indicators.

\subsection{Suggestion and limitation}

There are some limitations of this study. First, the data analyzed in this study is only limited to those revealed by the 20 best universities in Indonesia in 2017. It would be better if the next research adds to the sampled universities and adds data from the reports disclosed in the previous year. Second, the assessment in this study uses a checklist technique with a 1-0 rating and performed by one coder. To reduce subjectivity, subsequent researches could use a rating model of 0-4 and be performed by 2 or more coders. Finally, preferably, universities disclose more sustainability information related to green buildings and curricula in addition to creating an integrated sustainability report to facilitate communication with stakeholders who wish to access sustainability information. Integrated sustainability information disclosure will improve comparability and can illustrate the extent to which universities contribute to sustainable development.

\section{Reference}

Alonso-Almeida, Maria del Mar, Frederic Marimon, Fernando Casani, and Jesus RodriguezPomeda. 2014. "Diffusion of Sustainability Reporting in Universities: Current Situation and Future Perspectives." Journal of Cleaner Production 106: 144-54. https://doi.org/10.1016/j.jclepro.2014.02.008.

Amaral, Luís P., Nelson Martins, and Joaquim B. Gouveia. 2015. "Quest for a Sustainable University: a Review." International Journal of Sustainability in Higher Education 16 (2): 155-72. https://doi.org/10.1108/IJSHE-02-2013-0017.

Bengtsson, Mariette. 2016. "How to Plan and Perform a Qualitative Study Using Content Analysis.” NursingPlus Open 2: 8-14. https://doi.org/10.1016/j.npls.2016.01.001. 
Brundtland, Gro H. 1987. "Our Common Future: Report of the World Commission on Environment and Development." United Nations Commission. Vol. 4. https://doi.org/10.1080/07488008808408783.

Dabija, And-Cristian, Cătălin Postelnicu, Vasile Dinu, and Alin Mihăilă. 2017. "Stakeholders' Perception of Sustainability Orientation Within a Major Romanian University." International Journal of Sustainability in Higher Education 18 (4): 533-53. https://doi.org/10.1108/IJSHE-10-2015-0169.

Dabija, And Cristian, and Raluca Băbuţ. 2013. “An Approach to Sustainable Development from Tourists' Perspective. Empirical Evidence in Romania.” Amfiteatru Economic 15 (7): 617 33.

Dalal-Clayton, Barry, and Stephen Bass. 2002. Sustainable Development Strategies: A Resource Book. London: Earthscan Publications Ltd.

Downe-Wamboldt, Barbara. 1992. "Content Analysis: Method, Applications, and Issues." Health Care for Women International $13 \quad$ (3): 313-21. https://doi.org/10.1080/07399339209516006.

Fonseca, Alberto, Amanda Macdonald, Emily Anddy, and Paul Valenti. 2011. "The State of Sustainability Reporting at Canadian Universities. ” International Journal of Sustainability in Higher Education 12 (1): 22-40. https://doi.org/10.1108/14676371111098285.

Freeman, R E. 1984. Strategic Management: A Stakeholder Approach. Vol. 1. Boston: Pitman.

Garde, Raquel, Manuel Pedro Rodríguez, and Antonio M López. 2013. “Divulgación Online de Información de Responsabilidad Social en Las Universidades Españolas." Revista de Educación, no. Número extraordinario: 177-209. https://doi.org/10.4438/1988-592X-RE2013-EXT-246.

Global Reporting Initiative. 2014. "G4 Sustainability Reporting Guidelines.” Global Reporting Initiative, 1-97. https://www.globalreporting.org/standards/g4/Pages/default.aspx.

—. 2018. “About GRI.” 2018. Www.globalreporting.org/information/aboutgri/Pages/default.aspx.

Godemann, Jasmin, Jan Bebbington, Christian Herzig, and Jeremy Moon. 2014. "Higher Education and Sustainable Development Exploring Possibilities for Organisational Change." Accounting Auditing \& Accountability Journal 27 (2): 218-33. https://doi.org/10.1108/AAAJ-12-2013-1553.

Krippendorff, Klaus. 1991. Content Analysis: Introduction to its Theory and Methodology. Edited by Farid Wajidi. Jakarta: Rajawali Pers.

. 2004. Content Analysis: An Introduction to Its Methodology. London: SAGE Publications.

Lindblom, C. K. 1994. “The Implications of Organizational Legitimacy for Corporate Social Performance and Disclosure.” In Critical Perspectives on Accounting Conference. 
Lozano, Rodrigo. 2006a. "A Tool for a Graphical Assessment of Sustainability in Universities (GASU)." Journal of Cleaner Production $14 \quad$ (9-11): 963-72. https://doi.org/10.1016/j.jclepro.2005.11.041.

. 2006b. "Incorporation and Institutionalization of SD into Universities: Breaking Through Barriers to Change." Journal of Cleaner Production 14 (9-11): 787-96. https://doi.org/10.1016/j.jclepro.2005.12.010.

- 2011. "The State of Sustainability Reporting in Universities." International Journal of Sustainability in Higher Education 12 (1): 67-78. https://doi.org/10.1108/14676371111098311.

Lozano, Rodrigo, Kim Ceulemans, Mar Alonso-Almeida, Donald Huisingh, Francisco J. Lozano, Tom Waas, Wim Lambrechts, Rebeka Lukman, and Jean Hugé. 2015. “A Review of Commitment and Implementation of Sustainable Development in Higher Education: Results From a Worldwide Survey." Journal of Cleaner Production 108: 1-18. https://doi.org/10.1016/j.jclepro.2014.09.048.

Lozano, Rodrigo, and Don Huisingh. 2011. "Inter-Linking Issues and Dimensions in Sustainability Reporting." Journal of Cleaner Production 19 (2-3): 99-107. https://doi.org/10.1016/j.jclepro.2010.01.004.

Lozano, Rodrigo, Rebeka Lukman, Francisco J. Lozano, Donald Huisingh, and Wim Lambrechts. 2013. "Declarations for Sustainability in Higher Education: Becoming Better Leaders, Through Addressing the University System." In Journal of Cleaner Production, 48:10-19. https://doi.org/10.1016/j.jclepro.2011.10.006.

Marshall, Scott, Vlad Vaiman, Nancy Napier, Sully Taylor, Arno Haslberger, and Torben Andersen. 2010. "The End of a 'Period': Sustainability and the Questioning Attitude." Academy of Management Learning and Education 9 (3): 477-87. https://doi.org/10.5465/AMLE.2010.53791828.

Milne, Markus J., and Ralph W. Adler. 1999. "Exploring the Reliability of Social and Environmental Disclosures Content Analysis." Accounting, Auditing \& Accountability Journal 12 (2): 237-56. https://doi.org/10.1108/09513579910270138.

Newport, Dave, Thomas Chesnes, and Angela Lindner. 2003. "The 'Environmental Sustainability’ Problem: Ensuring that Sustainability Stands on Three Legs.” International Journal of Sustainability in Higher Education 4 (4): 357-63. https://doi.org/10.1108/14676370310497570.

Orr, D.W., and D.J Eagan. 1992. Campus and Environmental Responsibility. San Fransisco: Jossey-Bass.

Polit, Denise F., and Cheryl Tatano. Beck. 2006. Essentials of Nursing Research: Methods, Appraisal, and Utilization. Philadelphia: Lippincott Williams \& Wilkins. https://doi.org/10.1017/CBO9781107415324.004. 
Sekaran, Uma, and Roger Bougie. 2013. Research Methods for Business. 6ed. West Sussex: John Wiley \& Sons. https://doi.org/10.1017/CBO9781107415324.004.

Suchman, M. C. 1995. "Managing Legitimacy: Strategic and Institutional Approaches." Academy of Management Review $20 \quad$ (3): 571-610. https://doi.org/10.5465/AMR.1995.9508080331.

UNESCO. 1977. "The Tbilisi Declaration.” Intergovernmental Conference on Environmental Education, no. October: 1-96.

—. 2005. "United Nations Decade of Education for Sustainable Development ( 2005-2014 ): International Implementation Scheme.” Sustainable Development, no. October 2005: 32. https://doi.org/10.1007/s13398-014-0173-7.2.

- 2015. "Draft Preliminary Report Concerning the Preparation of a Global Convention on the Recognition of Higher Education Qualifications," 1-35.

Unesco-Unep. 1976. "The Belgrade Charter." Connect: UNESCO-UNEP Environmental Education Newsletter. Vol. 1. https://doi.org/10.1007/BF02220144.

Viebahn, P. 2002. “An Environmental Management Model for Universities: From Environmental Guidelines to Staff Involvement." Journal of Cleaner Production 10 (1): 3 12. https://doi.org/10.1016/S0959-6526(01)00017-8.

Zachariou, A., M. Kaila, and A. Katsikis. 2008. "Sustainable School: Facts, Objectives and Prospects." Science and Technology Topics in Education 1 (3): 269-88.

Zohrabi, Mohammad. 2013. "Mixed Method Research: Instruments, Validity, Reliability and Reporting Findings." Theory and Practice in Language Studies 3 (2): 254-62. https://doi.org/10.4304/tpls.3.2.254-262.

Zorio-Grima, Ana, Laura Sierra-García, and Maria A. Garcia-Benau. 2018. "Sustainability Reporting Experience by Universities: A Causal Configuration Approach." International Journal of Sustainability in Higher Education 19 (2): 337-52. https://doi.org/10.1108/IJSHE-07-2016-0142. 
THE INDONESIAN JOURNAL OF ACCOUNTING RESEARCH

Vol. 21, No. 3, September 2018 | http://ijar-iaikapd.or.id | DOI 10.33312/ijar.400

Page 363 - 394

\section{Appendix}

Appendix 1:

List of Rankings and Universities Codes

\begin{tabular}{|c|l|l|}
\hline Rank & University Name & Code \\
\hline 1 & Universitas Gadjah Mada & UGM \\
\hline 2 & Institut Teknologi Bandung & ITB \\
\hline 3 & Institut Pertanian Bogor & IPB \\
\hline 4 & Universitas Indonesia & UI \\
\hline 5 & Institut Teknologi Sepuluh Nopember & ITS \\
\hline 6 & Universitas Diponegoro & UD \\
\hline 7 & Universitas Airlangga & UA \\
\hline 8 & Universitas Brawijaya & UB \\
\hline 9 & Universitas Hasanuddin & UH \\
\hline 10 & Universitas Negeri Yogyakarta & UNY \\
\hline 11 & Universitas Sebelas Maret & UNS \\
\hline 12 & Universitas Andalas & UAN \\
\hline 13 & Universitas Pendidikan Indonesia & UPI \\
\hline 14 & Universitas Padjajaran & UP \\
\hline 15 & Universitas Negeri Malang & UNM \\
\hline 16 & Universitas Negeri Semarang & UNES \\
\hline 17 & Universitas Udayana & UU \\
\hline 18 & Universitas Lampung & UL \\
\hline 19 & Universitas Sumatera Utara & USU \\
\hline 20 & Universitas Jember & UJ \\
\hline
\end{tabular}

Appendix 2:

List of GRI G4 Categories and Indicators and Campus Sustainability assessment instruments developed by Fonseca et al. (2011).

\begin{tabular}{|c|l|}
\hline No & Category and Indicator \\
\hline & General Standard Disclosure \\
\hline 1 & Strategy and Analysis \\
\hline 2 & Organizational Profile \\
\hline 3 & Identified Material Aspects and Boundaries \\
\hline
\end{tabular}




\begin{tabular}{|c|l|}
\hline No & Category and Indicator \\
\hline 4 & Stakeholders Engagement \\
\hline 5 & Report Profile \\
\hline 6 & Governance \\
\hline 7 & Ethics and Integrity \\
\hline & Specific Standard Disclosures \\
\hline & Economic \\
\hline 8 & Economic Performance \\
\hline 9 & Market Presence \\
\hline 10 & Indirect Economic Impacts \\
\hline 11 & Procurement Practices \\
\hline & Environmental \\
\hline 12 & Materials \\
\hline 13 & Energy \\
\hline 14 & Water \\
\hline 15 & Biodiversity \\
\hline 16 & Emissions \\
\hline 17 & Effluents and Waste \\
\hline 18 & Products and Services \\
\hline 19 & Compliance \\
\hline 20 & Transport \\
\hline 21 & Overall \\
\hline 22 & Supplier Environmental Assesment \\
\hline 23 & Environmental Grievance Mechanisms \\
\hline & Labor Practices and Decent Work \\
\hline 24 & Employment \\
\hline 25 & Labor/Management Relations \\
\hline 26 & Occupational Health and Safety \\
\hline 27 & Training and Education \\
\hline 28 & Diversity and Equal Opportunity \\
\hline 29 & Equal Remuneration for Women and Men \\
\hline 30 & Supplier Assessment for Labor Practices \\
\hline & Labor Practices Grievance Mechanisms \\
\hline & Human Rights \\
\hline & \\
\hline & \\
\hline & \\
\hline &
\end{tabular}


The Indonesian Journal of Accounting Research - Sep, Vol. 21 , No.3, 2018

\begin{tabular}{|c|c|}
\hline No & Category and Indicator \\
\hline 32 & Investment \\
\hline 33 & Non-discrimination \\
\hline 34 & Freedom of Association and Collective Bargaining \\
\hline 35 & Child Labor \\
\hline 36 & Forced or Compulsory Labor \\
\hline 37 & Security Practices \\
\hline 38 & Indigenous Right \\
\hline 39 & Assessment \\
\hline 40 & Supplier Human Rights Assessment \\
\hline \multirow[t]{2}{*}{41} & Human Rights Grievance Mechanisms \\
\hline & Society \\
\hline 42 & Local Communities \\
\hline 43 & Anti-Corruption \\
\hline 44 & Public Policy \\
\hline 45 & Anti-competitive Behavior \\
\hline 46 & Compliance \\
\hline 47 & Supplier Assessment for Impacts on Society \\
\hline \multirow[t]{2}{*}{48} & Grievance Mechanisms for Impacts on Society \\
\hline & Product Responsibility \\
\hline 49 & Customer Health and Safety \\
\hline 50 & Product and Service Labeling \\
\hline 51 & Market Communications \\
\hline 52 & Customer Privacy \\
\hline \multirow[t]{3}{*}{53} & Compliance \\
\hline & Campus Sustainability Assessment Instrument \\
\hline & Research \\
\hline 54 & Policies Related to Sustainability in Research \\
\hline 55 & Research Centres/Labs Related to Sustainability \\
\hline 56 & Sustainability-related Research Programs \\
\hline 57 & Incentives to Sustainability Research \\
\hline 58 & Funding and Grants for Sustainability Research \\
\hline 59 & Academic Production Related to Sustainability \\
\hline 60 & Sustainability-related Research Projects \\
\hline
\end{tabular}




\begin{tabular}{|l|l|}
\hline No & Category and Indicator \\
\hline & Curriculum and Teaching \\
\hline 61 & Policies Related to Sustainability in Curriculum \\
\hline 62 & Courses Related to Sustainability \\
\hline 63 & Students Taking Sustainability-related Courses \\
\hline 64 & Sustainability Literacy Assessment \\
\hline 65 & Degree Programs Related to Sustainability \\
\hline 66 & Non-curricular Teaching Initiatives Related to Sustainability \\
\hline 67 & Scholarships Offered to Sustainability-related Education \\
\hline & Green Buildings and Procurement \\
\hline 68 & Green Buildings and Renovations \\
\hline 69 & Green Spaces \\
\hline 70 & Food Services \\
\hline 71 & Recycled Paper \\
\hline 72 & Green Electronics \\
\hline 73 & Green Furniture \\
\hline & \\
\hline
\end{tabular}

Appendix 3: 
The Indonesian Journal of Accounting Research - Sep, Vol. 21 , No.3, 2018

Process of Quantitative Content Analysis (Bengtsson 2016)

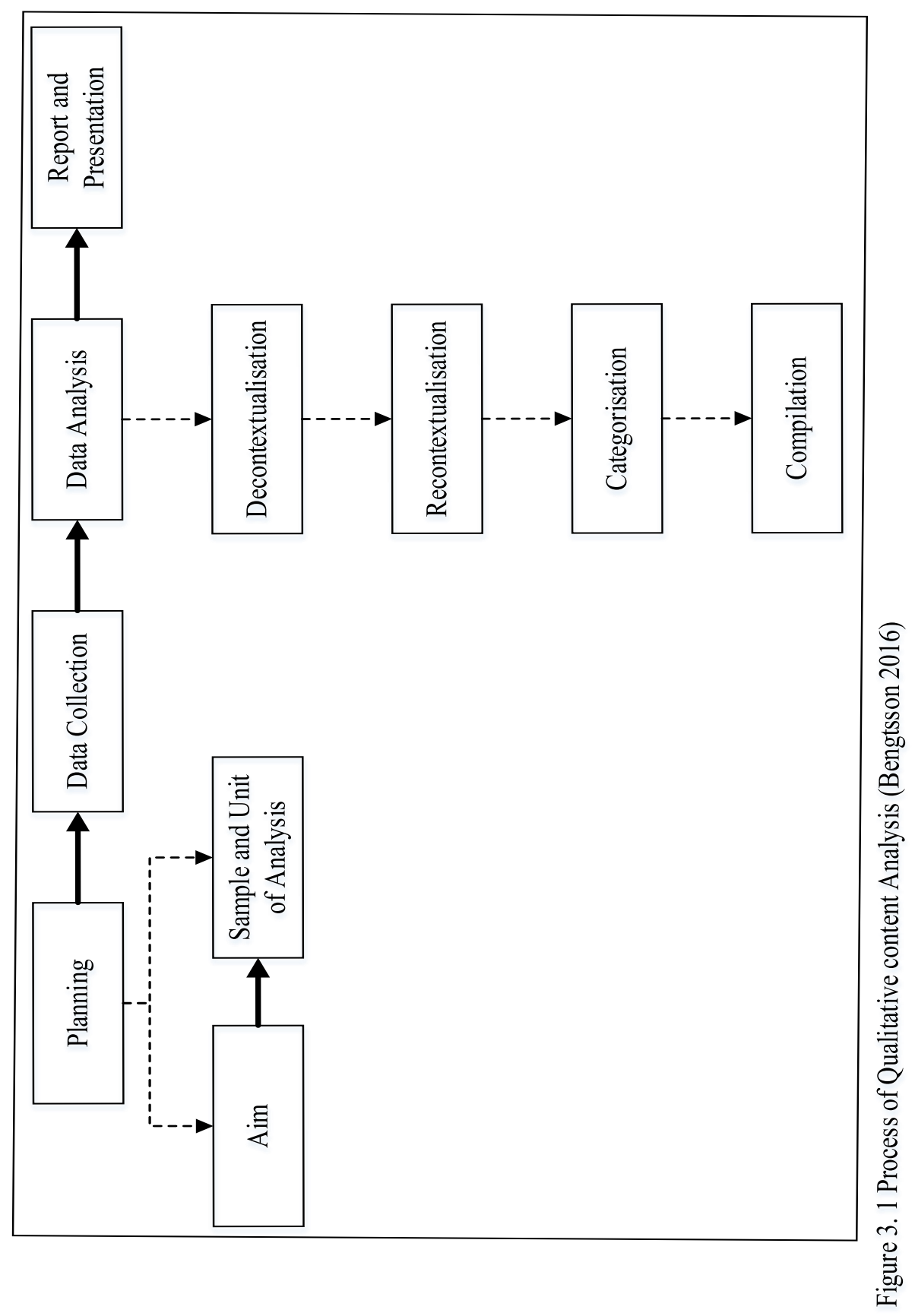


Appendix 4: Suitability of Sustainability Information Disclosure by Universities with GRI G4 Standards and Campus Sustainability Assessment Instruments

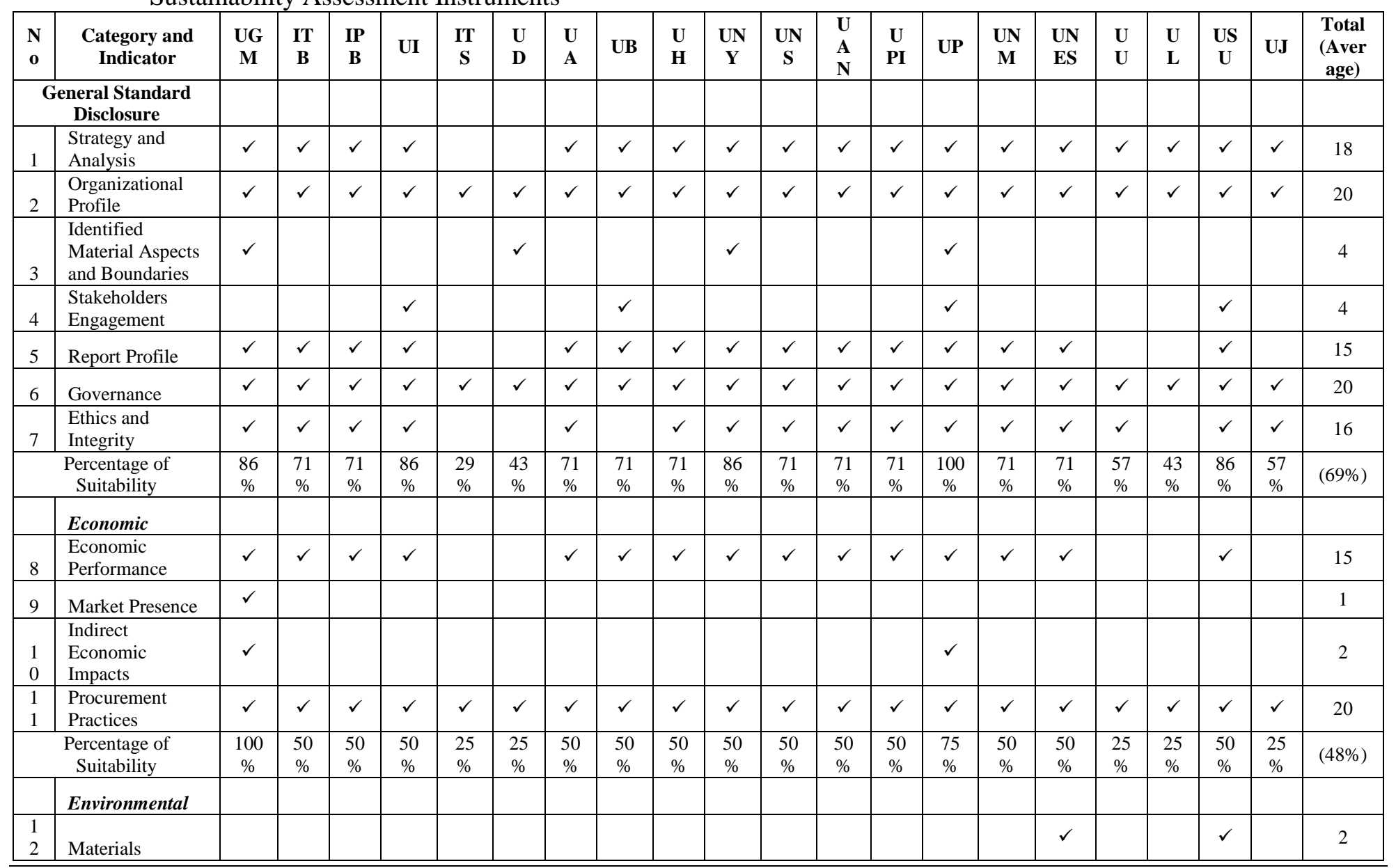

*Corresponding author: zuni.b@ugm.ac.id 
The Indonesian Journal of Accounting Research - Sep, Vol. 21 , No.3, 2018

\begin{tabular}{|c|c|c|c|c|c|c|c|c|c|c|c|c|c|c|c|c|c|c|c|c|c|c|}
\hline $\begin{array}{l}\mathbf{N} \\
\mathbf{o}\end{array}$ & $\begin{array}{l}\text { Category and } \\
\text { Indicator }\end{array}$ & $\begin{array}{c}\text { UG } \\
\mathbf{M}\end{array}$ & $\begin{array}{l}\text { IT } \\
\text { B }\end{array}$ & $\begin{array}{l}\text { IP } \\
\text { B }\end{array}$ & UI & $\begin{array}{l}\text { IT } \\
\mathrm{S}\end{array}$ & $\begin{array}{l}\text { U } \\
\text { D }\end{array}$ & $\begin{array}{l}\mathbf{U} \\
\mathbf{A}\end{array}$ & UB & $\begin{array}{l}\mathbf{U} \\
\mathbf{H}\end{array}$ & $\begin{array}{c}\text { UN } \\
\mathbf{Y}\end{array}$ & $\begin{array}{c}\text { UN } \\
\mathbf{S}\end{array}$ & $\begin{array}{l}\mathbf{U} \\
\mathbf{A} \\
\mathbf{N}\end{array}$ & $\begin{array}{l}\mathbf{U} \\
\mathbf{P I}\end{array}$ & UP & $\begin{array}{c}\mathbf{U N} \\
\mathbf{M}\end{array}$ & $\begin{array}{l}\text { UN } \\
\text { ES }\end{array}$ & $\begin{array}{l}\mathbf{U} \\
\mathbf{U}\end{array}$ & $\begin{array}{l}\mathbf{U} \\
\mathbf{L}\end{array}$ & $\begin{array}{l}\mathbf{U S} \\
\mathbf{U}\end{array}$ & UJ & $\begin{array}{c}\text { Total } \\
\text { (Aver } \\
\text { age) } \\
\end{array}$ \\
\hline $\begin{array}{l}1 \\
3 \\
\end{array}$ & Energy & $\checkmark$ & & & $\checkmark$ & $\checkmark$ & & & & & & & & & $\checkmark$ & & $\checkmark$ & & & $\checkmark$ & & 6 \\
\hline $\begin{array}{l}1 \\
4\end{array}$ & Water & $\checkmark$ & & & & & & & & & & & & & & & & & & $\checkmark$ & & 2 \\
\hline $\begin{array}{l}1 \\
5\end{array}$ & Biodiversity & & & $\checkmark$ & & & & & $\checkmark$ & & & & $\checkmark$ & & & & $\checkmark$ & $\checkmark$ & & & & 5 \\
\hline $\begin{array}{l}1 \\
6\end{array}$ & Emissions & & & & & $\checkmark$ & & & & & & & & & & & $\checkmark$ & & & $\checkmark$ & & 3 \\
\hline $\begin{array}{l}1 \\
7\end{array}$ & $\begin{array}{l}\text { Effluents and } \\
\text { Waste }\end{array}$ & & & & & $\checkmark$ & & & & & & & & & & & $\checkmark$ & & & $\checkmark$ & & 3 \\
\hline $\begin{array}{l}1 \\
8\end{array}$ & $\begin{array}{l}\text { Products and } \\
\text { Services }\end{array}$ & $\checkmark$ & $\checkmark$ & $\checkmark$ & $\checkmark$ & & $\checkmark$ & $\checkmark$ & $\checkmark$ & $\checkmark$ & $\checkmark$ & $\checkmark$ & $\checkmark$ & $\checkmark$ & $\checkmark$ & $\checkmark$ & $\checkmark$ & $\checkmark$ & $\checkmark$ & $\checkmark$ & $\checkmark$ & 19 \\
\hline $\begin{array}{l}1 \\
9 \\
\end{array}$ & Compliance & & & & & & & & & & & & & & & & & & & & & 0 \\
\hline $\begin{array}{l}2 \\
0\end{array}$ & Transport & $\checkmark$ & & $\checkmark$ & $\checkmark$ & $\checkmark$ & & $\checkmark$ & & & & $\checkmark$ & $\checkmark$ & & $\checkmark$ & $\checkmark$ & $\checkmark$ & & & $\checkmark$ & & 11 \\
\hline $\begin{array}{l}2 \\
1\end{array}$ & Overall & & & & & & & & & & & & & & & & $\checkmark$ & & & & & 1 \\
\hline $\begin{array}{l}2 \\
2\end{array}$ & $\begin{array}{l}\text { Supplier } \\
\text { Environmental } \\
\text { Assesment }\end{array}$ & & & & & & & & & & & & & & & & & & & & & 0 \\
\hline $\begin{array}{l}2 \\
3 \\
\end{array}$ & $\begin{array}{l}\text { Environmental } \\
\text { Grievance } \\
\text { Mechanisms }\end{array}$ & & $\checkmark$ & & $\checkmark$ & $\checkmark$ & $\checkmark$ & & & & & $\checkmark$ & & & & & $\checkmark$ & & $\checkmark$ & & $\checkmark$ & 8 \\
\hline & $\begin{array}{l}\text { Percentage of } \\
\text { Suitability }\end{array}$ & $\begin{array}{l}33 \\
\%\end{array}$ & $\begin{array}{l}17 \\
\%\end{array}$ & $\begin{array}{l}25 \\
\%\end{array}$ & $\begin{array}{l}33 \\
\%\end{array}$ & $\begin{array}{l}42 \\
\%\end{array}$ & $\begin{array}{l}17 \\
\%\end{array}$ & $\begin{array}{l}17 \\
\%\end{array}$ & $\begin{array}{l}17 \\
\%\end{array}$ & $\begin{array}{l}8 \\
\%\end{array}$ & $8 \%$ & $\begin{array}{l}25 \\
\%\end{array}$ & $\begin{array}{l}25 \\
\%\end{array}$ & $\begin{array}{l}8 \\
\%\end{array}$ & $\begin{array}{l}25 \\
\%\end{array}$ & $\begin{array}{l}17 \\
\%\end{array}$ & $\begin{array}{l}75 \\
\%\end{array}$ & $\begin{array}{l}17 \\
\%\end{array}$ & $\begin{array}{l}17 \\
\%\end{array}$ & $\begin{array}{l}58 \\
\%\end{array}$ & $\begin{array}{l}17 \\
\%\end{array}$ & $(25 \%)$ \\
\hline & $\begin{array}{l}\text { Labor Practices } \\
\text { and Decent } \\
\text { Work }\end{array}$ & & & & & & & & & & & & & & & & & & & & & \\
\hline $\begin{array}{l}2 \\
4 \\
\end{array}$ & Employment & $\checkmark$ & & & $\checkmark$ & $\checkmark$ & & & & & $\checkmark$ & $\checkmark$ & & $\checkmark$ & $\checkmark$ & & $\checkmark$ & & & $\checkmark$ & & 9 \\
\hline $\begin{array}{l}2 \\
5\end{array}$ & $\begin{array}{l}\text { Labor/Manageme } \\
\text { nt Relations }\end{array}$ & & & & & & & & & & $\checkmark$ & & & & & & & & & & & 1 \\
\hline $\begin{array}{l}2 \\
6\end{array}$ & $\begin{array}{l}\text { Occupational } \\
\text { Health and Safety }\end{array}$ & $\checkmark$ & & & & & & & & & & & & & & & $\checkmark$ & & & & & 2 \\
\hline
\end{tabular}




\begin{tabular}{|c|c|c|c|c|c|c|c|c|c|c|c|c|c|c|c|c|c|c|c|c|c|c|}
\hline $\begin{array}{l}\mathbf{N} \\
\mathbf{o}\end{array}$ & $\begin{array}{l}\text { Category and } \\
\text { Indicator }\end{array}$ & $\begin{array}{l}\text { UG } \\
\mathbf{M}\end{array}$ & $\begin{array}{l}\text { IT } \\
\text { B }\end{array}$ & $\begin{array}{l}\text { IP } \\
\text { B }\end{array}$ & UI & $\begin{array}{l}\text { IT } \\
\mathrm{S}\end{array}$ & $\begin{array}{l}\text { U } \\
\text { D }\end{array}$ & $\begin{array}{l}\mathbf{U} \\
\mathbf{A}\end{array}$ & UB & $\begin{array}{l}\mathbf{U} \\
\mathbf{H}\end{array}$ & $\begin{array}{c}\text { UN } \\
\mathbf{Y}\end{array}$ & $\begin{array}{c}\text { UN } \\
\text { S }\end{array}$ & $\begin{array}{l}\mathbf{U} \\
\mathbf{A} \\
\mathbf{N}\end{array}$ & $\begin{array}{c}\mathbf{U} \\
\mathbf{P I}\end{array}$ & $\mathbf{U P}$ & $\begin{array}{l}\text { UN } \\
\text { M }\end{array}$ & $\begin{array}{l}\text { UN } \\
\text { ES }\end{array}$ & $\begin{array}{l}\mathbf{U} \\
\mathbf{U}\end{array}$ & $\begin{array}{l}\mathbf{U} \\
\mathbf{L}\end{array}$ & $\begin{array}{c}\mathbf{U S} \\
\mathbf{U}\end{array}$ & $\mathbf{U J}$ & $\begin{array}{c}\text { Total } \\
\text { (Aver } \\
\text { age) }\end{array}$ \\
\hline $\begin{array}{l}2 \\
7\end{array}$ & $\begin{array}{l}\text { Training and } \\
\text { Education }\end{array}$ & $\checkmark$ & & & $\checkmark$ & $\checkmark$ & & & & & $\checkmark$ & $\checkmark$ & & & $\checkmark$ & & $\checkmark$ & & & $\checkmark$ & & 8 \\
\hline $\begin{array}{l}2 \\
8 \\
\end{array}$ & $\begin{array}{l}\text { Diversity and } \\
\text { Equal } \\
\text { Opportunity }\end{array}$ & & & & $\checkmark$ & & & & & & & & & & & & $\checkmark$ & & & & & 2 \\
\hline $\begin{array}{l}2 \\
9 \\
\end{array}$ & $\begin{array}{l}\text { Equal } \\
\text { Remuneration for } \\
\text { Women and Men }\end{array}$ & $\checkmark$ & & & $\checkmark$ & & & & & & & & & & $\checkmark$ & & $\checkmark$ & & & $\checkmark$ & & 5 \\
\hline $\begin{array}{l}3 \\
0\end{array}$ & $\begin{array}{l}\text { Supplier } \\
\text { Assessment for } \\
\text { Labor Practices }\end{array}$ & & & & & & & & & & & & & & & & & & & & & 0 \\
\hline $\begin{array}{l}3 \\
1\end{array}$ & $\begin{array}{l}\text { Labor Practices } \\
\text { Grievance } \\
\text { Mechanisms }\end{array}$ & & $\checkmark$ & & $\checkmark$ & $\checkmark$ & $\checkmark$ & & & & & $\checkmark$ & & & & & $\checkmark$ & & $\checkmark$ & & $\checkmark$ & 8 \\
\hline & $\begin{array}{l}\text { Percentage of } \\
\text { Suitability }\end{array}$ & $\begin{array}{l}50 \\
\% \\
\end{array}$ & $\begin{array}{l}13 \\
\% \\
\end{array}$ & $\begin{array}{c}0 \\
\% \\
\end{array}$ & $\begin{array}{l}63 \\
\% \\
\end{array}$ & $\begin{array}{l}38 \\
\% \\
\end{array}$ & $\begin{array}{l}13 \\
\% \\
\end{array}$ & $\begin{array}{c}0 \\
\% \\
\end{array}$ & $0 \%$ & $\begin{array}{c}0 \\
\% \\
\end{array}$ & $\begin{array}{l}38 \\
\% \\
\end{array}$ & $\begin{array}{l}38 \\
\% \\
\end{array}$ & $0 \%$ & $\begin{array}{l}13 \\
\% \\
\end{array}$ & $\begin{array}{l}38 \\
\% \\
\end{array}$ & $0 \%$ & $\begin{array}{l}75 \\
\% \\
\end{array}$ & $\begin{array}{c}0 \\
\% \\
\end{array}$ & $\begin{array}{l}13 \\
\% \\
\end{array}$ & $\begin{array}{l}38 \\
\% \\
\end{array}$ & $\begin{array}{l}13 \\
\% \\
\end{array}$ & $(22 \%)$ \\
\hline & Human Rights & & & & & & & & & & & & & & & & & & & & & \\
\hline $\begin{array}{l}3 \\
2\end{array}$ & Investment & & & & & & & & & & & & & & & & & & & & & 0 \\
\hline $\begin{array}{l}3 \\
3 \\
\end{array}$ & $\begin{array}{l}\text { Non- } \\
\text { discrimination }\end{array}$ & & & & & $\checkmark$ & & & & & & & & & $\checkmark$ & & $\checkmark$ & & & & & 3 \\
\hline $\begin{array}{l}3 \\
4 \\
\end{array}$ & $\begin{array}{l}\text { Freedom of } \\
\text { Association and } \\
\text { Collective } \\
\text { Bargaining } \\
\end{array}$ & & & & & & & & & & $\checkmark$ & & & & & & & & & & & 1 \\
\hline $\begin{array}{l}3 \\
5 \\
\end{array}$ & Child Labor & & & & & & & & & & & & & & & & & & & & & 0 \\
\hline $\begin{array}{l}3 \\
6 \\
\end{array}$ & $\begin{array}{l}\text { Forced or } \\
\text { Compulsory } \\
\text { Labor }\end{array}$ & & & & & & & & & & & & & & & & & & & & & 0 \\
\hline $\begin{array}{l}3 \\
7 \\
\end{array}$ & $\begin{array}{l}\text { Security } \\
\text { Practices }\end{array}$ & & & & $\checkmark$ & & & & $\checkmark$ & & $\checkmark$ & & & & & & & & & $\checkmark$ & & 4 \\
\hline $\begin{array}{l}3 \\
8 \\
\end{array}$ & Indigenous Right & & & & & & & & & & & & & & & & & & & & & 0 \\
\hline $\begin{array}{l}3 \\
9 \\
\end{array}$ & Asesment & & & & & & & & & & & & & & & & & & & & & 0 \\
\hline
\end{tabular}


The Indonesian Journal of Accounting Research - Sep, Vol. 21 , No.3 , 2018

\begin{tabular}{|c|c|c|c|c|c|c|c|c|c|c|c|c|c|c|c|c|c|c|c|c|c|c|}
\hline $\begin{array}{l}\mathbf{N} \\
\mathbf{o}\end{array}$ & $\begin{array}{l}\text { Category and } \\
\text { Indicator }\end{array}$ & $\begin{array}{c}\text { UG } \\
\mathbf{M}\end{array}$ & $\begin{array}{c}\text { IT } \\
\text { B }\end{array}$ & $\begin{array}{c}\text { IP } \\
\text { B }\end{array}$ & UI & $\begin{array}{l}\text { IT } \\
\text { S }\end{array}$ & $\begin{array}{l}\mathbf{U} \\
\mathbf{D}\end{array}$ & $\begin{array}{l}\mathbf{U} \\
\mathbf{A}\end{array}$ & UB & $\begin{array}{l}\mathbf{U} \\
\mathbf{H}\end{array}$ & $\begin{array}{c}\mathbf{U N} \\
\mathbf{Y}\end{array}$ & $\begin{array}{c}\mathbf{U N} \\
\mathbf{S}\end{array}$ & $\begin{array}{l}\mathbf{U} \\
\mathbf{A} \\
\mathbf{N}\end{array}$ & $\begin{array}{l}\mathbf{U} \\
\mathbf{P I}\end{array}$ & $\mathbf{U P}$ & $\begin{array}{l}\text { UN } \\
\mathbf{M}\end{array}$ & $\begin{array}{l}\text { UN } \\
\text { ES }\end{array}$ & $\begin{array}{l}\mathbf{U} \\
\mathbf{U}\end{array}$ & $\begin{array}{l}\mathbf{U} \\
\mathbf{L}\end{array}$ & $\begin{array}{l}\mathbf{U S} \\
\mathbf{U}\end{array}$ & $\mathbf{U J}$ & $\begin{array}{c}\text { Total } \\
\text { (Aver } \\
\text { age) }\end{array}$ \\
\hline $\begin{array}{l}4 \\
0 \\
\end{array}$ & $\begin{array}{l}\text { Supplier Human } \\
\text { Rights } \\
\text { Assessment } \\
\end{array}$ & & & & & & & & & & & & & & & & & & & & & 0 \\
\hline $\begin{array}{l}4 \\
1 \\
\end{array}$ & $\begin{array}{l}\text { Human Rights } \\
\text { Grievance } \\
\text { Mechanisms }\end{array}$ & & $\checkmark$ & & $\checkmark$ & $\checkmark$ & $\checkmark$ & & & & & $\checkmark$ & & & & & $\checkmark$ & & $\checkmark$ & & $\checkmark$ & 8 \\
\hline & $\begin{array}{l}\text { Percentage of } \\
\text { Suitability }\end{array}$ & $0 \%$ & $\begin{array}{l}10 \\
\%\end{array}$ & $\begin{array}{l}0 \\
\%\end{array}$ & $\begin{array}{l}20 \\
\%\end{array}$ & $\begin{array}{l}20 \\
\%\end{array}$ & $\begin{array}{l}10 \\
\%\end{array}$ & $\begin{array}{l}0 \\
\%\end{array}$ & $\begin{array}{l}10 \\
\%\end{array}$ & $\begin{array}{l}0 \\
\%\end{array}$ & $\begin{array}{l}20 \\
\%\end{array}$ & $\begin{array}{l}10 \\
\%\end{array}$ & $0 \%$ & $\begin{array}{l}0 \\
\%\end{array}$ & $\begin{array}{l}10 \\
\%\end{array}$ & $0 \%$ & $\begin{array}{l}20 \\
\%\end{array}$ & $\begin{array}{l}0 \\
\%\end{array}$ & $\begin{array}{l}10 \\
\%\end{array}$ & $\begin{array}{l}10 \\
\%\end{array}$ & $\begin{array}{l}10 \\
\%\end{array}$ & $(8 \%)$ \\
\hline & Society & & & & & & & & & & & & & & & & & & & & & \\
\hline $\begin{array}{l}4 \\
2 \\
\end{array}$ & $\begin{array}{l}\text { Local } \\
\text { Communities }\end{array}$ & $\checkmark$ & & & $\checkmark$ & & & & $\checkmark$ & & $\checkmark$ & $\checkmark$ & & $\checkmark$ & $\checkmark$ & $\checkmark$ & $\checkmark$ & & & $\checkmark$ & & 10 \\
\hline $\begin{array}{l}4 \\
3 \\
\end{array}$ & Anti-Corruption & & & & & & & & & & & $\checkmark$ & & & & & & & & & & 1 \\
\hline $\begin{array}{l}4 \\
4 \\
\end{array}$ & Public Policy & & & & $\checkmark$ & & & & & & & & & & $\checkmark$ & & $\checkmark$ & & & & & 3 \\
\hline $\begin{array}{l}4 \\
5 \\
\end{array}$ & $\begin{array}{l}\text { Anti-competitive } \\
\text { Behavior }\end{array}$ & & & & & & & & & & & & & & & & $\checkmark$ & & & & & 1 \\
\hline $\begin{array}{l}4 \\
6 \\
\end{array}$ & Compliance & & & & $\checkmark$ & & & & & & & & & & & & & & & & & 1 \\
\hline $\begin{array}{l}4 \\
7 \\
\end{array}$ & $\begin{array}{l}\text { Supplier } \\
\text { Assessment for } \\
\text { Impacts on } \\
\text { Society } \\
\end{array}$ & & & & & & & & & & & & & & & & & & & & & 0 \\
\hline $\begin{array}{l}4 \\
8 \\
\end{array}$ & $\begin{array}{l}\text { Grievance } \\
\text { Mechanisms for } \\
\text { Impacts on } \\
\text { Society } \\
\end{array}$ & & $\checkmark$ & & $\checkmark$ & $\checkmark$ & $\checkmark$ & & & & & $\checkmark$ & & & & & $\checkmark$ & & $\checkmark$ & & $\checkmark$ & 8 \\
\hline & $\begin{array}{l}\text { Percentage of } \\
\text { Suitability }\end{array}$ & $\begin{array}{l}14 \\
\%\end{array}$ & $\begin{array}{l}14 \\
\%\end{array}$ & $\begin{array}{l}0 \\
\%\end{array}$ & $\begin{array}{l}57 \\
\%\end{array}$ & $\begin{array}{l}14 \\
\%\end{array}$ & $\begin{array}{l}14 \\
\%\end{array}$ & $\begin{array}{l}0 \\
\%\end{array}$ & $\begin{array}{l}14 \\
\%\end{array}$ & $\begin{array}{l}0 \\
\%\end{array}$ & $\begin{array}{l}14 \\
\%\end{array}$ & $\begin{array}{l}43 \\
\%\end{array}$ & $0 \%$ & $\begin{array}{l}14 \\
\%\end{array}$ & $\begin{array}{l}29 \\
\%\end{array}$ & $\begin{array}{l}14 \\
\%\end{array}$ & $\begin{array}{l}57 \\
\%\end{array}$ & $\begin{array}{l}0 \\
\%\end{array}$ & $\begin{array}{l}14 \\
\%\end{array}$ & $\begin{array}{l}14 \\
\%\end{array}$ & $\begin{array}{l}14 \\
\%\end{array}$ & $(17 \%)$ \\
\hline & $\begin{array}{l}\text { Product } \\
\text { Responsibility }\end{array}$ & & & & & & & & & & & & & & & & & & & & & \\
\hline $\begin{array}{l}4 \\
9 \\
\end{array}$ & $\begin{array}{l}\text { Customer Health } \\
\text { and Safety }\end{array}$ & $\checkmark$ & & & $\checkmark$ & & & & & & & & & $\checkmark$ & $\checkmark$ & & $\checkmark$ & & & & & 5 \\
\hline $\begin{array}{l}5 \\
0 \\
\end{array}$ & $\begin{array}{l}\text { Product and } \\
\text { Service Labeling }\end{array}$ & $\checkmark$ & $\checkmark$ & $\checkmark$ & $\checkmark$ & $\checkmark$ & $\checkmark$ & $\checkmark$ & $\checkmark$ & $\checkmark$ & $\checkmark$ & $\checkmark$ & $\checkmark$ & $\checkmark$ & $\checkmark$ & $\checkmark$ & $\checkmark$ & $\checkmark$ & $\checkmark$ & $\checkmark$ & $\checkmark$ & 20 \\
\hline
\end{tabular}




\begin{tabular}{|c|c|c|c|c|c|c|c|c|c|c|c|c|c|c|c|c|c|c|c|c|c|c|}
\hline $\begin{array}{l}\mathbf{N} \\
\mathbf{o}\end{array}$ & $\begin{array}{l}\text { Category and } \\
\text { Indicator }\end{array}$ & $\begin{array}{c}\text { UG } \\
\mathbf{M}\end{array}$ & $\begin{array}{l}\text { IT } \\
\text { B }\end{array}$ & $\begin{array}{c}\text { IP } \\
\text { B }\end{array}$ & UI & $\begin{array}{c}\text { IT } \\
\mathrm{S}\end{array}$ & $\begin{array}{l}\mathbf{U} \\
\mathbf{D}\end{array}$ & $\begin{array}{l}\mathbf{U} \\
\mathbf{A}\end{array}$ & UB & $\begin{array}{l}\mathbf{U} \\
\mathbf{H}\end{array}$ & $\begin{array}{c}\text { UN } \\
\mathbf{Y}\end{array}$ & $\begin{array}{c}\text { UN } \\
\mathbf{S}\end{array}$ & $\begin{array}{l}\mathbf{U} \\
\mathbf{A} \\
\mathbf{N}\end{array}$ & $\begin{array}{l}\mathbf{U} \\
\mathbf{P I}\end{array}$ & UP & $\begin{array}{l}\mathbf{U N} \\
\mathbf{M}\end{array}$ & $\begin{array}{l}\text { UN } \\
\text { ES }\end{array}$ & $\begin{array}{l}\mathbf{U} \\
\mathbf{U}\end{array}$ & $\begin{array}{l}\mathbf{U} \\
\mathbf{L}\end{array}$ & $\begin{array}{l}\mathbf{U S} \\
\mathbf{U}\end{array}$ & $\mathbf{U J}$ & $\begin{array}{c}\text { Total } \\
\text { (Aver } \\
\text { age) }\end{array}$ \\
\hline $\begin{array}{l}5 \\
1 \\
\end{array}$ & $\begin{array}{l}\text { Market } \\
\text { Communications }\end{array}$ & & & $\checkmark$ & $\checkmark$ & & & & & & $\checkmark$ & & & & $\checkmark$ & & & & & & & 3 \\
\hline $\begin{array}{l}5 \\
2 \\
\end{array}$ & $\begin{array}{l}\text { Customer } \\
\text { Privacy } \\
\end{array}$ & & & & & & & & & & & & & & & & & & & & & 0 \\
\hline $\begin{array}{l}5 \\
3 \\
\end{array}$ & Compliance & & & & $\checkmark$ & & & & & & $\checkmark$ & & & & & & & & & & & 2 \\
\hline & $\begin{array}{c}\text { Percentage of } \\
\text { Suitability } \\
\end{array}$ & $\begin{array}{l}40 \\
\%\end{array}$ & $\begin{array}{l}20 \\
\% \\
\end{array}$ & $\begin{array}{l}40 \\
\%\end{array}$ & $\begin{array}{l}80 \\
\% \\
\end{array}$ & $\begin{array}{l}20 \\
\%\end{array}$ & $\begin{array}{l}20 \\
\% \\
\end{array}$ & $\begin{array}{l}20 \\
\% \\
\end{array}$ & $\begin{array}{l}20 \\
\%\end{array}$ & $\begin{array}{l}20 \\
\% \\
\end{array}$ & $\begin{array}{l}60 \\
\% \\
\end{array}$ & $\begin{array}{l}20 \\
\%\end{array}$ & $\begin{array}{l}20 \\
\%\end{array}$ & $\begin{array}{l}40 \\
\% \\
\end{array}$ & $\begin{array}{l}60 \\
\% \\
\end{array}$ & $\begin{array}{l}20 \\
\% \\
\end{array}$ & $\begin{array}{l}40 \\
\% \\
\end{array}$ & $\begin{array}{l}20 \\
\% \\
\end{array}$ & $\begin{array}{l}20 \\
\% \\
\end{array}$ & $\begin{array}{l}20 \\
\%\end{array}$ & $\begin{array}{l}20 \\
\%\end{array}$ & $(30 \%)$ \\
\hline & Research & & & & & & & & & & & & & & & & & & & & & \\
\hline $\begin{array}{l}5 \\
4 \\
\end{array}$ & $\begin{array}{l}\text { Policies Related } \\
\text { to Sustainability } \\
\text { in Research }\end{array}$ & $\checkmark$ & $\checkmark$ & $\checkmark$ & $\checkmark$ & $\checkmark$ & & & $\checkmark$ & $\checkmark$ & $\checkmark$ & $\checkmark$ & & $\checkmark$ & $\checkmark$ & $\checkmark$ & $\checkmark$ & & & $\checkmark$ & & 14 \\
\hline $\begin{array}{l}5 \\
5 \\
\end{array}$ & $\begin{array}{l}\text { Research } \\
\text { Centres/Labs } \\
\text { Related to } \\
\text { Sustainability } \\
\end{array}$ & $\checkmark$ & $\checkmark$ & $\checkmark$ & $\checkmark$ & $\checkmark$ & $\checkmark$ & $\checkmark$ & $\checkmark$ & $\checkmark$ & $\checkmark$ & $\checkmark$ & $\checkmark$ & $\checkmark$ & $\checkmark$ & $\checkmark$ & $\checkmark$ & $\checkmark$ & $\checkmark$ & $\checkmark$ & & 19 \\
\hline $\begin{array}{l}5 \\
6 \\
\end{array}$ & $\begin{array}{l}\text { Sustainability- } \\
\text { related Research } \\
\text { Programs }\end{array}$ & & $\checkmark$ & $\checkmark$ & $\checkmark$ & $\checkmark$ & $\checkmark$ & & $\checkmark$ & $\checkmark$ & $\checkmark$ & $\checkmark$ & & $\checkmark$ & $\checkmark$ & $\checkmark$ & $\checkmark$ & & & $\checkmark$ & & 14 \\
\hline $\begin{array}{l}5 \\
7\end{array}$ & $\begin{array}{l}\text { Incentives to } \\
\text { Sustainability } \\
\text { Research }\end{array}$ & & & & $\checkmark$ & $\checkmark$ & & & $\checkmark$ & & $\checkmark$ & $\checkmark$ & & & $\checkmark$ & & $\checkmark$ & & & & & 7 \\
\hline $\begin{array}{l}5 \\
8 \\
\end{array}$ & $\begin{array}{l}\text { Funding and } \\
\text { Grants for } \\
\text { Sustainability } \\
\text { Research }\end{array}$ & & $\checkmark$ & & $\checkmark$ & $\checkmark$ & & & $\checkmark$ & & $\checkmark$ & $\checkmark$ & $\checkmark$ & & $\checkmark$ & & $\checkmark$ & & & $\checkmark$ & & 10 \\
\hline $\begin{array}{l}5 \\
9 \\
\end{array}$ & $\begin{array}{l}\text { Academic } \\
\text { Production } \\
\text { Related to } \\
\text { Sustainability } \\
\end{array}$ & $\checkmark$ & $\checkmark$ & & $\checkmark$ & $\checkmark$ & $\checkmark$ & $\checkmark$ & $\checkmark$ & & $\checkmark$ & $\checkmark$ & & & $\checkmark$ & $\checkmark$ & $\checkmark$ & & & $\checkmark$ & & 13 \\
\hline $\begin{array}{l}6 \\
0\end{array}$ & $\begin{array}{l}\text { Sustainability- } \\
\text { related Research } \\
\text { Projects }\end{array}$ & & $\checkmark$ & $\checkmark$ & $\checkmark$ & $\checkmark$ & $\checkmark$ & & $\checkmark$ & $\checkmark$ & $\checkmark$ & $\checkmark$ & & $\checkmark$ & $\checkmark$ & $\checkmark$ & $\checkmark$ & & & $\checkmark$ & & 14 \\
\hline & $\begin{array}{l}\text { Percentage of } \\
\text { Suitability }\end{array}$ & $\begin{array}{l}43 \\
\% \\
\end{array}$ & $\begin{array}{l}86 \\
\% \\
\end{array}$ & $\begin{array}{l}57 \\
\% \\
\end{array}$ & $\begin{array}{c}100 \\
\%\end{array}$ & $\begin{array}{c}100 \\
\%\end{array}$ & $\begin{array}{l}57 \\
\% \\
\end{array}$ & $\begin{array}{l}29 \\
\% \\
\end{array}$ & $\begin{array}{c}100 \\
\%\end{array}$ & $\begin{array}{l}57 \\
\% \\
\end{array}$ & $\begin{array}{c}100 \\
\%\end{array}$ & $\begin{array}{c}100 \\
\%\end{array}$ & $\begin{array}{l}29 \\
\%\end{array}$ & $\begin{array}{l}57 \\
\% \\
\end{array}$ & $\begin{array}{c}100 \\
\%\end{array}$ & $\begin{array}{l}71 \\
\% \\
\end{array}$ & $\begin{array}{c}100 \\
\%\end{array}$ & $\begin{array}{l}14 \\
\%\end{array}$ & $\begin{array}{l}14 \\
\%\end{array}$ & $\begin{array}{l}86 \\
\% \\
\end{array}$ & $\begin{array}{c}0 \\
\% \\
\end{array}$ & $(65 \%)$ \\
\hline
\end{tabular}


The Indonesian Journal of Accounting Research - Sep, Vol. 21 , No.3, 2018

\begin{tabular}{|c|c|c|c|c|c|c|c|c|c|c|c|c|c|c|c|c|c|c|c|c|c|c|}
\hline $\begin{array}{l}\mathbf{N} \\
\mathbf{o}\end{array}$ & $\begin{array}{l}\text { Category and } \\
\text { Indicator }\end{array}$ & $\begin{array}{c}\text { UG } \\
\mathbf{M}\end{array}$ & $\begin{array}{l}\text { IT } \\
\text { B }\end{array}$ & $\begin{array}{l}\text { IP } \\
\text { B }\end{array}$ & UI & $\begin{array}{l}\text { IT } \\
\mathrm{S}\end{array}$ & $\begin{array}{l}\text { U } \\
\text { D }\end{array}$ & $\begin{array}{l}\mathbf{U} \\
\mathbf{A}\end{array}$ & UB & $\begin{array}{l}\mathbf{U} \\
\mathbf{H}\end{array}$ & $\begin{array}{c}\mathbf{U N} \\
\mathbf{Y}\end{array}$ & $\begin{array}{c}\text { UN } \\
\mathbf{S}\end{array}$ & $\begin{array}{l}\mathbf{U} \\
\mathbf{A} \\
\mathbf{N}\end{array}$ & $\begin{array}{l}\mathbf{U} \\
\mathbf{P I}\end{array}$ & UP & $\begin{array}{l}\mathbf{U N} \\
\mathbf{M}\end{array}$ & $\begin{array}{l}\text { UN } \\
\text { ES }\end{array}$ & $\begin{array}{l}\mathbf{U} \\
\mathbf{U}\end{array}$ & $\begin{array}{l}\mathbf{U} \\
\mathbf{L}\end{array}$ & $\begin{array}{l}\mathbf{U S} \\
\mathbf{U}\end{array}$ & $\mathbf{U J}$ & $\begin{array}{c}\text { Total } \\
\text { (Aver } \\
\text { age) } \\
\end{array}$ \\
\hline & $\begin{array}{l}\text { Curriculum and } \\
\text { Teaching }\end{array}$ & & & & & & & & & & & & & & & & & & & & & \\
\hline $\begin{array}{l}6 \\
1\end{array}$ & $\begin{array}{l}\text { Policies Related } \\
\text { to Sustainability } \\
\text { in Curriculum }\end{array}$ & $\checkmark$ & & $\checkmark$ & $\checkmark$ & & & & & & $\checkmark$ & & $\checkmark$ & $\checkmark$ & $\checkmark$ & & $\checkmark$ & & & & & 8 \\
\hline $\begin{array}{l}6 \\
2 \\
\end{array}$ & $\begin{array}{l}\text { Courses Related } \\
\text { to Sustainability }\end{array}$ & & & & $\checkmark$ & & & & & & $\checkmark$ & & & & & & $\checkmark$ & & & & & 3 \\
\hline $\begin{array}{l}6 \\
3 \\
\end{array}$ & $\begin{array}{l}\text { Students Taking } \\
\text { Sustainability- } \\
\text { related Courses }\end{array}$ & & & & & & & & & & & & & & & & & & & & & 0 \\
\hline $\begin{array}{l}6 \\
4\end{array}$ & $\begin{array}{l}\text { Sustainability } \\
\text { Literacy } \\
\text { Assessment }\end{array}$ & & & $\checkmark$ & & & & & & & & & & & & & & & & & & 1 \\
\hline $\begin{array}{l}6 \\
5\end{array}$ & $\begin{array}{l}\text { Degree Programs } \\
\text { Related to } \\
\text { Sustainability }\end{array}$ & & & & $\checkmark$ & & & & & & $\checkmark$ & & & & $\checkmark$ & & $\checkmark$ & & & & & 4 \\
\hline $\begin{array}{l}6 \\
6 \\
\end{array}$ & $\begin{array}{l}\text { Non-curricular } \\
\text { Teaching } \\
\text { Initiatives } \\
\text { Related to } \\
\text { Sustainability }\end{array}$ & & & $\checkmark$ & $\checkmark$ & & & & & & $\checkmark$ & & & & $\checkmark$ & & $\checkmark$ & & & & $\checkmark$ & 6 \\
\hline $\begin{array}{l}6 \\
7\end{array}$ & $\begin{array}{l}\text { Scholarships } \\
\text { Offered to } \\
\text { Sustainability- } \\
\text { related Education }\end{array}$ & & $\checkmark$ & $\checkmark$ & $\checkmark$ & & & & $\checkmark$ & $\checkmark$ & $\checkmark$ & $\checkmark$ & & & $\checkmark$ & & $\checkmark$ & $\checkmark$ & $\checkmark$ & & $\checkmark$ & 12 \\
\hline & $\begin{array}{l}\text { Percentage of } \\
\text { Suitability }\end{array}$ & $\begin{array}{l}14 \\
\%\end{array}$ & $\begin{array}{l}14 \\
\%\end{array}$ & $\begin{array}{l}57 \\
\%\end{array}$ & $\begin{array}{l}71 \\
\%\end{array}$ & $0 \%$ & $\begin{array}{l}0 \\
\%\end{array}$ & $\begin{array}{l}0 \\
\%\end{array}$ & $\begin{array}{l}14 \\
\%\end{array}$ & $\begin{array}{l}14 \\
\%\end{array}$ & $\begin{array}{l}71 \\
\%\end{array}$ & $\begin{array}{l}14 \\
\%\end{array}$ & $\begin{array}{l}14 \\
\%\end{array}$ & $\begin{array}{l}14 \\
\%\end{array}$ & $\begin{array}{l}57 \\
\%\end{array}$ & $0 \%$ & $\begin{array}{l}71 \\
\%\end{array}$ & $\begin{array}{l}14 \\
\%\end{array}$ & $\begin{array}{l}14 \\
\%\end{array}$ & $\begin{array}{l}0 \\
\%\end{array}$ & $\begin{array}{l}29 \\
\%\end{array}$ & $(24 \%)$ \\
\hline & $\begin{array}{l}\text { Green Buildings } \\
\text { and } \\
\text { Procurement }\end{array}$ & & & & & & & & & & & & & & & & & & & & & \\
\hline $\begin{array}{l}6 \\
8 \\
\end{array}$ & $\begin{array}{l}\text { Green Buildings } \\
\text { and Renovations }\end{array}$ & & & & $\checkmark$ & & $\checkmark$ & & $\checkmark$ & & & & & & $\checkmark$ & & $\checkmark$ & & & & & 5 \\
\hline $\begin{array}{l}6 \\
9 \\
\end{array}$ & Green Spaces & $\checkmark$ & & $\checkmark$ & $\checkmark$ & $\checkmark$ & & & $\checkmark$ & & & & & & $\checkmark$ & & $\checkmark$ & & & $\checkmark$ & & 8 \\
\hline $\begin{array}{l}7 \\
0\end{array}$ & Food Services & $\checkmark$ & $\checkmark$ & $\checkmark$ & & & & & $\checkmark$ & & & & & $\checkmark$ & & & & & & & & 5 \\
\hline
\end{tabular}




\begin{tabular}{|c|c|c|c|c|c|c|c|c|c|c|c|c|c|c|c|c|c|c|c|c|c|c|}
\hline $\begin{array}{l}\mathbf{N} \\
\mathbf{o}\end{array}$ & $\begin{array}{l}\text { Category and } \\
\text { Indicator }\end{array}$ & $\begin{array}{c}\text { UG } \\
\mathbf{M}\end{array}$ & $\begin{array}{l}\text { IT } \\
\text { B }\end{array}$ & $\begin{array}{l}\text { IP } \\
\text { B }\end{array}$ & UI & $\begin{array}{l}\text { IT } \\
\mathrm{S}\end{array}$ & $\begin{array}{l}\text { U } \\
\text { D }\end{array}$ & $\begin{array}{l}\mathbf{U} \\
\mathbf{A}\end{array}$ & UB & $\begin{array}{l}\mathbf{U} \\
\mathbf{H}\end{array}$ & $\begin{array}{c}\text { UN } \\
\mathbf{Y}\end{array}$ & $\begin{array}{c}\text { UN } \\
\text { S }\end{array}$ & $\begin{array}{l}\mathbf{U} \\
\mathbf{A} \\
\mathbf{N}\end{array}$ & $\begin{array}{l}\mathbf{U} \\
\mathbf{P I}\end{array}$ & UP & $\begin{array}{l}\text { UN } \\
\text { M }\end{array}$ & $\begin{array}{l}\text { UN } \\
\text { ES }\end{array}$ & $\begin{array}{l}\mathbf{U} \\
\mathbf{U}\end{array}$ & $\begin{array}{l}\mathbf{U} \\
\mathbf{L}\end{array}$ & $\begin{array}{l}\text { US } \\
\mathbf{U}\end{array}$ & UJ & $\begin{array}{c}\text { Total } \\
\text { (Aver } \\
\text { age) }\end{array}$ \\
\hline $\begin{array}{l}7 \\
1 \\
\end{array}$ & Recycled Paper & & & $\checkmark$ & & & & & & & & & & & & & $\checkmark$ & & & $\checkmark$ & & 3 \\
\hline $\begin{array}{l}7 \\
2\end{array}$ & $\begin{array}{l}\text { Green } \\
\text { Electronics }\end{array}$ & & & & $\checkmark$ & & & & & & & & & & & & & & & $\checkmark$ & & 2 \\
\hline $\begin{array}{l}7 \\
3\end{array}$ & Green Furniture & & & & & & & & & & & & & & & & & & & & & 0 \\
\hline & $\begin{array}{l}\text { Percentage of } \\
\text { Suitability }\end{array}$ & $\begin{array}{l}33 \\
\%\end{array}$ & $\begin{array}{l}17 \\
\%\end{array}$ & $\begin{array}{l}50 \\
\%\end{array}$ & $\begin{array}{l}50 \\
\% \\
\end{array}$ & $\begin{array}{l}17 \\
\%\end{array}$ & $\begin{array}{l}17 \\
\%\end{array}$ & $\begin{array}{l}0 \\
\%\end{array}$ & $\begin{array}{l}50 \\
\%\end{array}$ & $\begin{array}{l}0 \\
\%\end{array}$ & $0 \%$ & $0 \%$ & $0 \%$ & $\begin{array}{l}17 \\
\%\end{array}$ & $\begin{array}{l}33 \\
\% \\
\end{array}$ & $0 \%$ & $\begin{array}{l}50 \\
\% \\
\end{array}$ & $\begin{array}{l}0 \\
\%\end{array}$ & $\begin{array}{l}0 \\
\%\end{array}$ & $\begin{array}{l}50 \\
\% \\
\end{array}$ & $\begin{array}{l}0 \\
\%\end{array}$ & $(19 \%)$ \\
\hline & Total Indicator & 73 & 73 & 73 & 73 & 73 & 73 & 73 & 73 & 73 & 73 & 73 & 73 & 73 & 73 & 73 & 73 & 73 & 73 & 73 & 73 & \\
\hline & $\begin{array}{l}\text { tal Indicator being } \\
\text { Reported }\end{array}$ & 27 & 21 & 23 & 42 & 23 & 15 & 12 & 23 & 14 & 30 & 26 & 14 & 18 & 35 & 16 & 45 & 10 & 12 & 30 & 13 & $\begin{array}{c}(22,45 \\
)\end{array}$ \\
\hline & $\begin{array}{l}\text { Percentage of } \\
\text { Suitability }\end{array}$ & $\begin{array}{l}37 \\
\%\end{array}$ & $\begin{array}{l}29 \\
\%\end{array}$ & $\begin{array}{l}32 \\
\%\end{array}$ & $\begin{array}{l}58 \\
\%\end{array}$ & $\begin{array}{l}32 \\
\%\end{array}$ & $\begin{array}{l}21 \\
\%\end{array}$ & $\begin{array}{l}16 \\
\%\end{array}$ & $\begin{array}{l}32 \\
\%\end{array}$ & $\begin{array}{l}19 \\
\%\end{array}$ & $\begin{array}{l}41 \\
\%\end{array}$ & $\begin{array}{l}36 \\
\%\end{array}$ & $\begin{array}{l}19 \\
\%\end{array}$ & $\begin{array}{l}25 \\
\%\end{array}$ & $\begin{array}{l}48 \\
\%\end{array}$ & $\begin{array}{l}22 \\
\%\end{array}$ & $\begin{array}{l}62 \\
\%\end{array}$ & $\begin{array}{l}14 \\
\%\end{array}$ & $\begin{array}{l}16 \\
\%\end{array}$ & $\begin{array}{l}41 \\
\%\end{array}$ & $\begin{array}{l}18 \\
\%\end{array}$ & $(31 \%)$ \\
\hline
\end{tabular}


The Indonesian Journal of Accounting Research - Sep, Vol. 21 , No.3 , 2018

intentionally blank 